\title{
THE IMPLICATIONS OF THE DOMINANCE OF WOMEN IN THE ZIMBABWEAN MUSIC INDUSTRY FOR THE ORDINATION OF WOMEN
}

\author{
Lovemore Togarasei \\ Department of Religious Studies \\ Classics and Philosophy \\ University of Zimbabwe
}

\begin{abstract}
There are numerous questions on gender and theology that have to be addressed in the African context. This article focuses on the dominance of women in the Zimbabwean gospel music industry. It opens with a brief history of the place of women in traditional music in Zimbabwe, then discusses gospel music and the dominance of women in this type of music. The possible factors that cause the dominance of women in the gospel music industry are then considered. The article ends with a section on the theological implications of such dominance of women, focusing on the issue of women ordination. The article concludes that, if the dominance of women in African Christianity and the teaching of the New Testament are considered, there are no convincing grounds for denying women ordination.
\end{abstract}

\section{Introduction}

Gospel music has revolutionised the music industry in Zimbabwe. It has not only attracted followers from all age groups and social classes, it has also penetrated all sectors of the society. One can hear the music in churches, at wedding parties, at graduation parties, at birthday parties and even in beer gardens. There is, however, an interesting trend in Zimbabwean gospel music. Whereas, in other "secular" forms of music, men dominate, Zimbabwean gospel music is dominated by women. Why women have taken the gospel music industry by storm needs theological reflection that would address issues of gender in the African context.

\section{Women and Gospel Music before the Dawn of the Gospel Music Era}

Like many other African societies, Zimbabwe is a patriarchal society. This has to be taken into account in any analysis of the role of women in music in general. Indeed, women had a place in traditional music, they sang and danced at such rituals as burial and kurova guva (the ritual conducted to bring home the spirit of a deceased adult). ${ }^{1}$ However, such singing was usually done chorally and under the leadership of men who officiated at such rituals. Never could a woman stand in front of men, women and children, singing in order to educate and entertain them, as is done by female musicians today. This was because there were taboos in African ethnic groups that restricted women. As Anne Nasimiyu-Wasike argues, "(in African societies) women are not taken seriously, and at times their intelligence is belittled by men." 2 Though this is not true of all African societies, Nasimiyu-Wasike's

1. JL Cox, 1992. Expressing the Sacred: An Introduction to the Phenomenology of Religion. Harare: University of Zimbabwe Publications, 64-78.

2. A Namisiyu-Wasike, 1997. “Christology and an African Woman's Experience.” In Schreiter, RJ (ed.) Faces of Jesus in Africa. Maryknoll: Orbis Books, 71. 
observation is true of many African societies, including the Zimbabwean society that is the focus of this paper.

Considering this attitude to women, it is not surprising that, with the rise of modern music groups in Zimbabwe's urban areas in the 1930s, women continued to take the back seat in music performance. Chitando notes that traditional music in Zimbabwe underwent transformation in the late 1930s. ${ }^{3}$ The period marked the beginning of public music performances. Western music instruments began to replace traditional ones as music underwent commercialisation. Municipalities and private companies started sponsoring musical groups. TP Mapuranga correctly identifies a number of prominent musical groups, (such as Devera Ngwena Jazz Band sponsored by Shabani Mines), that were sponsored by private companies. ${ }^{4}$ This development further marginalised women in the gospel music industry. Music was played in beer halls and nightclubs, in most cases during the night. It was therefore believed that no "decent" women could be found performing at such places. Worse still, those women who decided to take part in such music performances were used as dancers and backing vocalists. In line with the type of music which was played, they usually had to wag their bottoms in a sexually suggestive manner. This further hampered the image of a woman musician. Society therefore started associating women musicians with loose morals.

But there were some women who withstood the social and cultural pressure and "invaded the public place." Not only did they become backing vocalists and dancers, some women also formed and led successful music groups. However, compared to the number of male-led groups, the number of female-led groups were, to say the least, insignificant. Although the number of women involved in music continued to increase with the coming of independence, it was only with the dawn of gospel music in Zimbabwe that female musicians flourished. Since the doors have been "opened" by female gospel musicians such as Shuvai Wutaunashe, the past three to four years have seen a sharp rise in the number of female musicians involved in other forms of music as well. Examples are Chioniso Maraire who sings traditional music and Plaxedes Wenyika who sings love songs.

\section{The Dominance of Women in Gospel Music}

That women enjoy the limelight in Zimbabwean gospel music is uncontested. Many writers ${ }^{6}$ concur and statistics also prove this. Watching television programmes on gospel music, listening to various radio programmes and reading newspapers on music reviews, one can count no less than twenty-five professional women gospel musicians. A gospel music concert in 2002 featured only female gospel musicians. At gospel music concerts women-led groups usually outnumber men-led groups. For example, at the launch show of Ngatimunate, Carol Chivengwa-Mujokoro's album, on Saturday 29 March 2003, there were eight women-led gospel groups against three men-led groups in the Harare Gardens. On the same day, across town, there were six female-led groups and four male-led groups in the Harare International Conference Centre. The following statistics on the Prime Gospel

3. Chitando, E 2002. Singing culture: A study of gospel music in Zimbabwe. Nordiska Afrikainstitutet. Research report no.121, 27.

4. Mapuranga, TP 2000. "The rise of Gospel music in Zimbabwe with particular reference to the role of women." BA (Hons) Dissertation, University of Zimbabwe.

5. Chitando, E 2001. "Female Missionaries: a Study of the Participation of Women in Zimbabwean Gospel music" in Journal of Constructive Theology Vol. 7, No.2, 53-71.

6. For example Chitando, E and Mapuranga, TP op. cit. 
Show, a TV programme presented each Sunday evening, provide a further indication of this trend:

\begin{tabular}{|c|c|c|}
\hline Date & $\begin{array}{c}\text { Number of female-led } \\
\text { gospel groups featured }\end{array}$ & $\begin{array}{c}\text { Number of male-led gospel } \\
\text { groups featured }\end{array}$ \\
\hline 11 May 2003 & 8 & 3 \\
\hline 18 May 2003 & 6 & 2 \\
\hline 8 June 2003 & 8 & 4 \\
\hline 15 June 2003 & 9 & 2 \\
\hline
\end{tabular}

The dominance of women in gospel music is further indicated by the fact that nearly all gospel music groups, even those led by men, feature women as backing vocalists. These include groups led by Elias Misawa, Pastor L Haisa, Pastor C Bandimba, Timothy Ngwenya's and many others. Whereas many secular music groups feature only men as singers (women usually feature only as dancers), this is not the case in gospel music. There are, in fact, allwomen gospel music groups where men only play the musical instruments. Fungisai Zvakavapano's and Ivy Kombo's groups are examples of such groups.

We have been discussing professional gospel musicians so far, but there are also many other women who are involved in gospel music. These include women who sing in church choirs and groups which tend to record one song and then disappear. These women have contributed greatly to the vibrancy of gospel music in Zimbabwe.

It is clear that women have dominated the gospel music industry in Zimbabwe. But, what factors have contributed to this phenomenon if one considers the place of women in Zimbabwe and, indeed, in Africa as a whole?

\section{Factors Influencing the Dominance of Women in Zimbabwean Gospel Music}

There are a number of factors that seem to influence the dominance of women in gospel music. I will discuss four such factors here. It should be noted that a combination of such factors may have contributed to this trend.

The first factor that can be identified is the decency with which gospel music is usually associated. We argued above that African women were inhibited by social pressure to expose themselves at such places as beer gardens where most musical groups played. The church therefore provided a socially acceptable alternative. As T Mapuranga argues, "Women who had a strong desire to become singers found solace in singing in churches as opposed to pubs, beer gardens, night clubs and other venues which were considered to be no go areas for women." ${ }^{, 7}$ Such gospel musicians are accepted by society. Whereas those involved in other forms of music were initially associated with weak morals, female gospel musicians have always been thought to be morally upright. S Manhando-Makore puts it aptly:

In Zimbabwe it is female gospel musicians who seem to enjoy a good image in society. Because they are singing about the goodness of God, they are often portrayed favourably, even if they perform at night. It is female pop musicians who are seen in a not so favourable light. $^{8}$

7. Mapuranga, TP op. cit., 44.

8. Mahando-Makore, S cited by E Chitando, 2001, op.cit., 60. 
Interestingly enough, these gospel musicians closely resemble others in the music industry. They jump, ululate, clap hands to entertain the listeners. However, society accepts them since they are believed to be driven by the spirit of God in their singing. No wonder Ivy Kombo scooped the 2002 Best Gospel Music group award at the National Arts Merits Awards. She is considered to be a role model by many youngsters. ${ }^{9}$

The decency associated with gospel music is also indicated by the support that husbands give to their wives who are involved in gospel music. Most husbands of female gospel musicians give them their full support. Shuvai Wutawunashe, Spiwe Chimuti, Shingisai Suluma and Olivia Charamba are examples of female gospel musicians who are strongly supported by their husbands.

The second factor that influences the dominance of women in gospel music is the history of music in the church. As Rev. C Chipere correctly notes, music in the church has always been dominated by women. ${ }^{10}$ This is further compounded by the fact that there are far more female than male Christians in Zimbabwe. It is no overstatement to suggest that more than seventy percent of Christians in Zimbabwe are women. It may therefore be expected that women dominate the music industry.

A third possible factor influencing the dominance of women in gospel music is ecclesiastical in nature. It seems that women have used gospel music as an alternative pulpit where women are not accepted into the ordained ministry. It has been used as a platform for preaching and teaching. Two factors seem to support this view. Firstly, nearly all leading female gospel musicians are from Pentecostal churches (Wutawunashe belongs to the Family of God, Carol Chivengwa Mujokoro, Ivy Kombo, Jack Madondo, Ruth Mapfumo belong to the Zimbabwe Assemblies of God, Spiwe Chimuti and Olivia Charamba belong to the Apostolic Faith Mission, Primrose Cement, Joyce Simeti and Fungisai Zvakavapano belong to Glad Tidings). Most Pentecostal churches do not ordain women as ministers. The Apostolic Faith Mission has started training women into ministry but in practice they have not yet been fully accepted as ministers. As Rev. Chipere said, only one woman runs a parish with the rest of the graduates being involved in clerical work and Sunday school services. ${ }^{11} \mathrm{~J}$ Kwaramba says that the ordination of women in the AFM was done only as a compromise and could not be extended to the giving of the Holy Communion. ${ }^{12}$

One may therefore be justified in suggesting that women have used gospel music to make their voice heard in ministry. Space and time does not allow us to analyse many of the songs in which women musicians tackle ecclesiastical issues. One example is Mrs Makawa who, in a song entitled Chechi Yangu (My Church), lambastes those pastors who claim to have the sole ownership of the church. She calls for repentance and criticises denominationalism. The second factor that seems to support the view that women use gospel music as an alternative pulpit is the fact that none of the gospel musicians is an ordained pastor, while there are many male gospel musicians who are pastors (e.g. T Chivaviro, E Musakwa, L Haisa, C Charamba, C Bandimba). From these two factors one can suggest that those women who feel they have been called to Christian ministry, use gospel music as an alternative in a situation where the church is against female ordination.

The fourth factor that may influence the dominance of women in gospel music appears to be the sharp nature of female voices. Women have sharp and more touching voices. As

9. Evidence from This is Life, a TV HIV/AIDS education programme of 8/06/03.

10. Rev. CR Chipere, Interview, Harare, 19/05/03.

11. Rev. CR Chipere, Interview, see note 10.

12. Kwaramba, J 2002. "An Investigation into the New Testament Interpretation of the role of women in the church by the Apostolic Faith Mission in Zimbabwe," BA (Hons) Dissertation, University of Zimbabwe, 26. 
Rev. T Chivaviro, a male gospel musician said, words and voice projections are more important in gospel music than the instruments played. ${ }^{13}$ Gospel music (unlike other forms of music where dance is emphasised), is supposed to touch the heart. The sharper female voices are better placed to achieve this than the harsher male voices. It is no wonder that male-led gospel groups feature a number of women who sing lead or backing vocals.

The above are some of the factors that seem to influence the dominance of women in the Zimbabwean gospel music industry. We now need to look at the theological implications that can be drawn from the domination of women in gospel music.

\section{Theological Implications}

Two insights have emerged from the discussion thus far. Firstly, it is a fact that women and children form a large percentage of African Christianity. Despite their numbers, women play second fiddle in churches in Zimbabwe. Secondly, it seems that women can indeed stimulate change in African Christianity, as is evident from the way Christian women in Zimbabwe have revolutionalised gospel music. These two lessons force us to revisit the issue of women's ordination. Many Christian denominations do not ordain women. The Roman Catholic Church, the Anglican Church and several Pentecostal churches are cases in point in Zimbabwe. They usually find their justification from the Bible, particularly from 1 Corinthians 14:34 and I Timothy 2:11-13. These two passages instruct women to be silent in church. They must not teach men but rather must always be submissive to their husbands:

Let a woman learn in silence with all submissiveness. I permit no woman to teach or to have authority over men, she is to keep silent (1 Timothy 2: $11-12)$.

Those against women's ordination argue that the practice would go against such passages. But, if the passages are to be taken literally, such people should not listen to gospel music by female artists. In their songs women musicians express their message in an oral form which is the dominant form of theological expression in Africa. ${ }^{14}$ In this way they do teach. As Kennedy Samanyanga writes, "Musicians have an equally vital role to play in any given society in shaping and upholding moral values." ${ }^{" 15}$ Musicians are therefore as influential in society as any other professionals. If ordained women can make a difference in society as Zimbabwe female gospel musicians have done, surely there is no basis for denying women access to the ordained ministry.

Denying women ordination on the basis of the above passages also has its problems. The interpretation of these passages is complex. A.C. Wire argues that in some manuscripts, for example Greek-Latin bilinguals or Latin texts, 1 Corinthians 14:34 - 35 comes at the end of that chapter suggesting that it could have been glossed there by a later editor. ${ }^{16}$ This position is supported by many scholars who observe that since Paul had allowed women to pray and prophesy if their heads are veiled (1 Corinthians 11), there is no way he could openly contradict himself by then commanding women to be silent in church. ${ }^{17}$ Subsequently, theologians of later centuries have nearly always interpreted 1

13. T Chivaviro, interview. Harare, 27 May 2003.

14. Togarasei, L 2003. "African Oral Theology: the case of Shona Christian songs" in Swedish Missiological Themes, 91, 1, 67-80.

15. Samanyanga, K 2003. "Musicians must spearhead political change.” The Daily News, 23 May 2003.

16. Wire, AC 1990. The Corinthian Women Prophets: A Recconstruction through Paul's Rhetoric. Minneapolis: Fortress Press, 149.

17. Gryson, R op. cit., p. 6. 
Corinthians 14:34-35 in the light of 1 Tim. 2:11-12 -which is believed to have come from late Judaism because of its anti-feminist tendency. ${ }^{18}$

I suggest that, given the problems relating to the interpretation of such passages that command women to be silent in church, contemporary theologians must also take other passages into consideration. There are many passages in the New Testament that show that women played an important role in Christianity from the very beginning. E. Schussler Fiorenza argues that the history of women in Christianity is a history that can be described in terms of the discipleship of equals. ${ }^{19}$ Jesus was accompanied by many women disciples (Luke 8:1-3, Mark 16:1-2). Many scholars have noted that Galatians 3:28 may be considered to be Paul's charter for liberation of women. Paul writes:

There is neither Jew nor Greek, there is neither slave nor free, there is neither male nor

female, for you are all one in Christ Jesus.

Paul must have been serious about this because in one of the churches he founded in Corinth, there was a deaconess (Romans 16:1). Our knowledge of deacons in the history of the church tells us that they were part of the church structure by the end of the first century. They cared for the needy, prepared new converts for baptism, read Scriptures in worship, and distributed the Lord's Supper. ${ }^{20}$ If first century women had such roles in the church, there is surely no basis for denying ordination to women in the twenty-first century where women have entered nearly all the institutions of life.

\section{Conclusion}

Considering the number of women in the churches, the fact that through gospel music women already play pastoral roles like teaching and counselling, I argue that there is no basis for denying women ordination. The New Testament passages used to deny them ordination are problematic and, as I have argued above, there are other New Testament passages that liberate women from the restrictions of culture and set them at the same level with their male counterparts. After all, the church must always be at the forefront of human emancipation. Liberating women for church ministry is one such way of emancipating women.

18. Ibid.

19. Fiorenza, ES 1988. In Memory of Her: A feminist Theological Reconstruction of Christian origins. New York: Crossroad, 97-151.

20. MacHaffie, BJ 1986. Her story: Women in Christian Tradition, Philadelphia: Fortress Press, 30. 


\section{BIBLIOGRAPHY}

Cox, JL 1992. Expressing the Sacred: An Introduction to the Phenomenology of Religion. Harare: University of Zimbabwe Publications.

Chitando, E 2001. Female Missionaries? A Study of the Participation of Women in Zimbabwean Gospel Music in Journal of Constructive Theology Vol. 7, No. 2, $53-71$.

Chitando, E 2002. Singing Culture: A Study of Gospel Music in Zimbabwe. Nordiska: Afrikainstitutet. Research Report no. 121.

Fiorenza, ES 1998. In Memory of Her: A Feminist Theological Reconstruction of Christian Origins. New York: Crossroad.

Gryson, R 1976. The Ministry of Women in the Early Church. Minnesota: The Liturgical Press.

Kwaramba, J 2002. "An Investigation Into The New Testament Interpretation of the Role of Women in the Church by the Apostolic Faith Mission in Zimbabwe: BA (Hons) Dissertation, University of Zimbabwe.

MacHaffie, BJ 1986. Her Story: Women in Christian Tradition. Philadelphia: Fortress Press.

Mapuranga, TP 2000. "The Rise of Gospel Music in Zimbabwe with a Special Reference to the Role of Women: BA (Hons) Dissertation, University of Zimbabwe.

Namusiyu-Wasike, A 1997. "Christology and an African Women's Experience in Schreiter, RJ (ed.). Faces of Jesus in Africa. Maryknoll: Orbis Books.

Samanyanga, K 2003. Musicians Must Spearhead Political Change, The Daily News, 23 May 2003.

Togarasei, L 2003. African Oral Theology: The Case of Shona Christian Songs' in Swedish Missiological Themes, 91, 1, $67-80$.

Wire, AC 1990. The Corinthian Women Prophets: A Reconstruction Through Paul's Rhetoric. Minneapolis: Fortress Press.

\section{Interviews}

Rev. Chipere, Charles R, Harare, 19 May 2003.

Rev. Chivaviro, Togarepi, Harare, 27 May 2003. 